\title{
Discourse Analysis of Metri Wayang Gandrung Oral Tradition
}

\author{
Febri Taufiqurrahman ${ }^{1}$, Karkono Karkono ${ }^{2}$, Moh. Safii ${ }^{3}$ \\ ${ }^{1}$ Universitas Negeri Malang \\ ${ }^{2}$ Universitas Negeri Malang \\ ${ }^{3}$ Universitas Negeri Malang \\ * Corresponding author.Email febri.taufiqurrahman.fs@um.ac.id
}

\begin{abstract}
Metri Wayang Gandrung is an oral tradition carried out by the people of Pagung Village, Kediri Regency when they have intentions and vows. This researcher was conducted by using qualitative and ethnographic methods. Data of spoken language was transcribed into a text of Metri Wayang Gandrung. The analysis of this research was carried out using a discourse analysis approach. The theory of discourse analysis used is the notion from Halliday \& Hasan [1] and Renkema [2]. To analyze the contextual meaning of the Javanese culture, the researcher used the idea from Rahyono (2009). The research findings obtained are Metri Wayang Gandrung text consists of three parts, namely introduction, content, and closing. In those three sections, 12 keywords are found as the core constituents that build the structure of sentences in the Metri Wayang Gandrung text. Of the twelve keywords was functioned as the predicate, 11 keywords were categorized as a verb and 1 keyword was categorized as a noun. The twelve keywords are the words suguh, metri / petri, dipunpanggénipun, gadahi / anggadahi, nyuwun, kaleksanan, tumpeng jejeg masumambang, dipunsanggupi, dipunturuti, anetepi, idéni, nyuwun ngapunten. Referring to the analysis of the referential and contextual meaning of culture, the twelve keywords construct a discourse meaning. The conclusion in this study is that the meaning of the discourse contains messages that can be seen from three aspects, namely functional aspects, social aspects, and aspects of community life.
\end{abstract}

Keywords: discourse, oral tradition, Metri Wayang Gandrung

\section{INTRODUCTION}

Wayang Gandrung is one of the oral tradition cultures that existed in Pagung Village, Semen District, Kediri Regency, East Java. Every Wayang Gandrung performance always begins with a ruwatan ritual or the local people call it metri which mean a ritual ceremony (similar to a slametan). The metri ritual is carried out by the local community before performing Wayang Gandrung or when they have certain intentions. Every metri ritual always uses an utterance which is usually called luaran ujar when carrying out the ceremony. Saying or uni which means "to make a promise" is the main requirement for this wayang performance. Without that saying, the show will never happen. The metri ritual ceremony, which is carried out beyond the story framework (play) of the performance, is a manifestation of the fulfilment of the promises from the host.

The metri performed by the ritual performers are only one of the mandatory prerequisites for carrying out the Wayang Gandrung performance and also realizing (ngujubaké) requests from people who have intentions or desires led by Brejonggo. A Brejonggo as an intermediary inherited the expertise in reading the metrical speech from the previous generation which came from the inventor of the tradition [3]. In that speech, Brejonggo uses Javanese with a variety of manners. The variety of krama is a form of the Javanese language manner with the core of the krama lexicon or which is the core element in the variety of krama. The krama 
lexicon includes the affixes dipun-, ipun, and aken. The speaker who in this case is referred to as Brejonggo deliberately uses Javanese variety of krama because the speech partner he is talking to is Wayang Gandrung who is considered to have a higher position as in the following sample data.

Kula suguh dhateng Mbah Gandrung... 'I (give) a meal to Mbah Gandrung....'

The sentence above is included in the Javanese speech variety of krama. This is evidenced by the word kula which is the form of the first personal pronoun variety of krama. The word kula has a function as a subject. Brejonggo as a speaker deliberately uses Javanese utterances with a variety of krama because he knows that the friends he is talking to are highly respected ancestors, namely Mbah Gandrung. Substantively, the words and the title Mbah contain deep respect for someone or something sacred. In the Javanese Baoesastra Dictionary [4], the word Mbah or embah has the meaning of 'wong tuwané bapa utawa biyung' (parents of the father or mother). The presence of the word kula 'I' as the subject of the sentence indicates that the persona mentioned by the speaker has a higher position than the speaker. Meanwhile, the word suguh has a function as a predicate. The word suguh means '(give) a dish'. As a predicate, the word suguh has a meaning relationship with the word kula which is located as the subject. How is the relationship between these meanings and whether the word suguh only has the meaning of '(giving) a dish' or has other meanings related to the context of Metri Wayang Gandrung.

\section{METHODOLOGY}

The method used in this study is qualitative using an ethnographic approach. Heigham and Robert [5] explain that qualitative research is using the main textual data collection and tests it using interpretive analysis. Rasinger in Litosseliti [6] explained that qualitative analysis is done by analyzing the text by paying attention to the characteristics or quality of the text. The ethnography was used because it requires the participation of researchers directly to be involved in a community environment that implements Metri Wayang Gandrung. This is done so that researchers can cooperate in collecting data and conducting this research comprehensively.

The data source used in this research is the video recording that was taken directly when Metri Wayang Gandrung was being performed. The results of the audio-visual recording had been transcribed from spoken language into written text. In this study, researchers took data from Metri
Wayang Gandrung which was held at the request of the community who had a desire on October 9, 2013. It was held at the request of $\mathrm{Mr}$ Pan Nurdianto (Ngadiyanto) from Balikpapan as primary data in this study.

The data collection and processing technique used in this research is using audio-visual recordings. The researcher performed the recording technique directly when the Metri Wayang Gandrung ritual was carried out. This study also used three methods of collecting data, namely participatory observation, periodic observation, and in-depth interviews [7]. Participatory observations were carried out so that data related to Metri's speech could be collected as a whole. Transcription was done manually by the researcher by listening directly to the audio-visual recording. Then, the transcribed data will be sorted based on the data in the form of sentences.

Sudaryanto [8] said that to be able to explain the authenticity of a sentence meaning, the identification must go through the aspects of syntactic categories, syntactic functions, and syntactic roles. First, it relates to the syntactic category. The syntactic constituents of single sentences in the Javanese language are abundantly categorized as phrases and not words. Second, it relates to the syntactic function. The syntactic function that forms the formal framework is a very abstract space, so the determination of its existence must involve its filler.

Halliday and Hasan [1] defined text as referring to a spoken or written discourse. A text has a texture that can distinguish between text and non-text. The texture is built through the relationship of cohesion. Cohesion refers to the relationship of meaning in a text. Cohesion occurs when the interpretation of several elements in discourse depends on each other. Halliday and Hasan [1] say that cohesion is the complete meaning contained in the text.

According to Kridalaksana [9], referential meaning is also referred to as denotation which is the opposite of connotation. Denotation is the meaning of a word or group of words based on a straightforward designation of something outside the language or based on certain conventions; it is objective [9]. The denotation of the meaning of a word or lexeme that still points to the basic referent that is following the facts is referred to as referential meaning, while the denotation of the meaning of a word or lexeme that is generated from 
the conceptual meaning of its users is referred to as conceptual meaning.

Therefore, the speech in Metri Wayang Gandrung is not only conveyed but also contains a message from what is to be conveyed to the public. The language construction used in Metri Wayang Gandrung contains meaning that builds a discourse. Therefore, based on the explanation of the background above, this study was conducted to analyze the meaning of discourse in the oral tradition of Metri Wayang Gandrung.

\section{ANALYSIS}

The identification of the Metri Wayang Gandrung text framework consists of 3 parts, including the opening, content, and closing which are built by 12 keywords that make up the Metri Wayang Gandrung text. The twelve keywords were analyzed for lexical and referential meaning. The analysis of the lexical meaning and referential meaning will be carried out thoroughly to find out the relationship between the meanings of the 12 keywords and other words that are present in the 20 sentences that make up the Metri Wayang Gandrung text. The analysis of the lexical and referential meaning of the 12 keywords is explained below.

3.1 Suguh (Serve). The word suguh comes from the lexeme suguh. In the Javanese Baoesastra Dictionary [4], the lexeme suguh (soegoeh) has the meaning of panganan la sapanunggalané sing diladéaké marang dayoh 'food and other things that is served to guests'. Referring to the lexical meaning, the word suguh is categorized as a noun that functioned as a predicate. However, the word suguh is categorized as a verb because it has zero derivation. The word suguh underwent a category shift from a noun to a verb without going through a morphological change of form. Thus, the lexical meaning of the word suguh is (ngewenéhi) lan sapanunggalané sing diladéaké marang dayoh '(giving) food and others things to the guests' or '(giving) dishes'. Based on the lexical meaning, the word suguh has been categorized as a verb that fills the function as a predicate. This is evidenced by the relationship between the meaning of the word suguh and the other constituents that accompany it. Thus, the referential meaning of the word suguh based on the relationship of meaning in the context of the cultural activities of Metri Wayang Gandrung oral tradition refers to an action that must be taken when Metri Wayang Gandrung. This action must be taken as a form of fulfilling the promise. The actions that must be taken are in the form of serving food and meeting the ancestors that have been mentioned, namely Mbah Gandrung jaler estri, Mbah Semar jaler estri, Mbah Jaka Luar jaler estri, Mbah Raden Sedana Papa jaler estri sapunggawanipun sedaya ingkang kula kawruhi, utawi dipunkawruhi buyut panjenengan Pak Ngadiyanto ingkang sowan dhateng panjenengan menika 'Male and female Mbah Gandrung, male and female Mbah Semar, male and female Mbah Jaka Luar, male and female Mbah Raden Sedana Papa, and their soldiers.'. The contextual meaning is as follows: First, if someone has a promise to get a certain desire, then that person must fulfil his promise when that desire has been achieved. Second, if someone is going to visit someone else's house, they should bring something (in the form of food or gifts) as a form of respect for the host.

3.2 Metri / Petri. In the Javanese Baoesastra Dictionary [4] the lexeme of petri or metri means opèni or 'treat'. Based on the lexical meaning, the word metri/petri is categorized as a verb that functions as a predicate. This is evidenced by the relationship between the meaning of the word suguh and the other constituents that accompany it. Thus, the referential meaning of the word suguh based on the relationship of meaning in the context of the cultural activities of the oral tradition of Metri Wayang Gandrung refers to an action in the form of the ability to care for the universe and protect the ancestors. As for the contextual meaning: First, humans must build good relations with the universe so that life can run well and safely. Second, people must protect their parents or ancestors by visiting them for those who are still alive or visiting their graves for those who are dead

3.3 Dipunpanggénipun. The word dipunpanggénipun comes from the lexeme panggénan which underwent a morphological process to get the affixes di-, pun-, -ipun. In the Javanese Baoesastra Dictionary [4] the word panggénan has the meaning of panggonan 'place'. Affixes di-, pun-, -ipun are markers of passive verb forms [10]. Thus, lexically, the word dipunpanggénipun has the meaning of being 'occupied'. This is evidenced by the relationship of the meaning of the word dipunpanggénipun with the other constituents that accompany it. Thus, the 
referential meaning of the word dipunpanggéni is based on the relationship of meaning in the context of the cultural activities of the oral tradition of Metri Wayang Gandrung referring to an act of occupying a land carried out by the children, grandchildren, and great-grandchildren of the ancestors. In this case, the occupied land is the residence of children, grandchildren, and great-grandchildren who have left their place of birth. As for the contextual meaning, it reminds people not to forget their ancestors even though they have left their homeland.

3.4 Nggadahi / Anggadahi. The word nggadahi or anggadahi comes from the same lexeme, namely gadah. The word nggadahi comes from the lexeme gadah which underwent a morphological process to get the $\mathrm{N}-/-\mathrm{i}$ affix [10]. While anggadahi derived from the gadah lexeme underwent a morphological process to get the affix a-, N- /-i [10]. In the Javanese Baosastra Dictionary [4] the lexeme gadah has the meaning doewé 'to have'. Thus, the lexical meaning of the word gadahi or anggadahi is doewéni 'to have'. Based on the lexical meaning, the word gadahilanggadahi has a category as a verb that function as a predicate. This is evidenced by the relationship of the meaning of the word gadahilanggadahi with other constituents that accompany it. Thus, the referential meaning of the word gadahilanggadahi based on the relationship of these meanings in the context of the cultural activities of the Metri Wayang Gandrung oral tradition refers to a state of the speaker who has a desire and promises to carry out certain activities if that desire has been successfully achieved. The promise refers to the ability to carry out Metri Wayang Gandrung activities. As for the contextual meaning: First, if someone previously had a promise because he wanted to get a certain desire, then that person must fulfil his promise when that desire has been achieved. Second, if the desire has been achieved, the person must fulfil his promise according to what has been said before.

3.5 Nyuwun. The word nyuwun comes from the lexeme suwun which underwent a morphological process to get the N-affix [10]. In the Javanese Baosastra Dictionary [4], the word nyuwun has the meaning of njaluk 'asking'. Based on the function analysis above, the word nyuwun is categorized as a verb and functions as a predicate. As for knowing the referential meaning of the word nyuwun, an analysis of the meaning relationship between the word nyuwun and the constituents that accompany it in the sentence structure is carried out. Based on the lexical meaning, the word nyuwun has a category as a verb that functions as a predicate. This is evidenced by the relationship between the meaning of the word nyuwun and the other constituents that accompany it. Thus, the referential meaning of the word nyuwun based on the relationship of meaning in the context of the cultural activities of the Metri Wayang Gandrung oral tradition refers to an act of asking for a position carried out by the speaker. The position refers to a certain position desired by the speaker. As for the contextual meaning: if someone has a certain desire, it should be conveyed to parents or ancestors to ask for a blessing. By asking for the blessing of parents or ancestors, this wish will be achieved. If this is related to the beliefs of the local community, it can be concluded that one of the easiest prayers to be answered is the prayer from parents for their children.

3.4 Kaleksanan. The word kaleksanan comes from the lexeme leksana which underwent a morphological process to get the affixes kaand -an. In the Javanese Baoesastra Dictionary [4], the word leksana has the meaning of 'implemented'. The forms of affixes ka- and -an which are attached to the basic form of the word leksana are markers of passive verb forms [10]. Thus, the lexical meaning of the word kaleksanan is 'implemented'. Based on the lexical meaning, the word kaleksanan has a category as a verb that functions as the predicate. This is evidenced by the relationship of the meaning of the word kaleksanan with the other constituents that accompany it. Thus, the referential meaning of the word kaleksanan based on the relationship of meaning in the context of the cultural activities of the Metri Wayang Gandrung oral tradition refers to a situation of getting a position as desired by the speaker. As for the contextual meaning: if humans try and work hard, they will get what they want.

3.5 Tumpeng jejeg maskumambang. The nominal phrase tumpeng jejeg maskumambang consists of three words, namely tumpeng, jejeg, and maskumambang. In the Javanese Baoesastra (Poerwadarminta, 1939:614,85,298), the word tumpeng has the 
meaning of sega diwangun pasungan (dianggo slametan) 'cone-shaped rice (used for slametan)', the word jejeg has the meaning of ora dhoyong 'not tilted', and the word maskumambang has the meaning of macapat song 'name of macapat song'. The three words are constituents to form a noun phrase tumpeng jejeg maskumambang which lexically means sega diwangun pasungan sing ora dhoyong 'rice formed by a cone that stands upright'. Based on the lexical meaning, the nominal phrase tumpeng jejeg maskumambang has a category as a noun that fills the function as a predicate. This is evidenced by the relationship between the meaning of the nominal phrase tumpeng jejeg maskumambang with other constituents that accompany it. Thus, the referential meaning of the nominal phrase tumpeng jejeg maskumambang based on the relationship of meaning in the context of the cultural activities of the oral tradition of Metri Wayang Gandrung refers to a dish called tumpeng jejeg maskumambang as a mandatory requirement in carrying out Metri Wayang Gandrung activities. As for the contextual meaning: First, humans must continue to uphold culture while still complying with the rules or conditions that must be carried out in carrying out the cultural tradition. Second, humans must be able to live sharing with others.

3.6 Dipunsanggupi. The word dipunsanggupi comes from the lexeme sanggup to get the affix dipun-/-i. In the Javanese Baoesastra Dictionary [4], the word sanggup have the meaning of saguh or arep nglakoni 'willing to undergo'. As for lexically, the word dipunsanggupi has the meaning of dilakoni "to be undergone". Based on the lexical meaning, the word dipunsanggupi is categorized as a verb that functions as a predicate. This is evidenced by the relationship between the meaning of the word and the other constituents that accompany it. Thus, the referential meaning of the word is carried out based on the relationship of meaning in the context of the cultural activities of the Metri Wayang Gandrung oral tradition referring to an action that must be taken to get a promotion as desired by the speaker. As for the contextual meaning: the ability of humans to fulfill promises according to what has been said before.

3.7 Idéni. The word idéni comes from the lexeme $i d i$ which underwent a morphological process to get the affix -ni [10]. In the Baoesastra Java Dictionary [4]) the lexeme idi has the meaning of palilah saka panggedé 'blessing or blessing from the Almighty'. Thus, lexically, the word ideni has the meaning of lilani saka panggedé '(asking for) blessing from the Almighty'. Based on the lexical meaning, the word idéni has a category as a verb that functions as a predicate. This is evidenced by the relationship of the meaning of the word idéni with the other constituents that accompany it. Thus, the referential meaning of the word idéni based on the relationship of meaning in the context of the cultural activities of the Metri Wayang Gandrung oral tradition refers to an action taken by the speaker in the form of asking for a blessing to the ancestors so that the Almighty will give the health and strength to the speaker and his family. As for the contextual meaning: so that humans do not forget that everything that happens in human life does not escape the supervision and will of the Almighty God. By asking for blessings from parents or ancestors, humans will always remember the Almighty God.

3.8 Dipunturuti. The word dipunturuti comes from the lexeme turut that gets the affix dipun-/-i [10]. In the Javanese Baoesastra Dictionary [4], lexemes turut have the meaning of manut 'obedient'. As for lexically, the word dipunturuti has the meaning of dileksanani panjaluke 'carrying out his request'. Based on the lexical meaning, the word turut is categorized as a verb that functions as a predicate. This is evidenced by the relationship the meaning of the word dipunturuti by the other constituents that accompany it. Thus, the referential meaning of the word dipunturuti based on the relationship of meaning in the context of the cultural activities of the oral tradition of Metri Wayang Gandrung referring to a condition in the form of a willingness to carry out Metri Wayang Gandrung activities because the speaker's wishes have been obtained. As for the contextual meaning: so that humans are willing to fulfill their promises according to what has been said before.

3.9 Anetepi. The word anetepi comes from the lexeme netep which underwent a morphological process to get the affix a-/-i [10]. The word netep in the Javanese Baoesastra Dictionary [4] has the meaning of manjing kenceng, tetep. Thus, the word anetepi has the lexical meaning of nglakoni 
tumrap kawajiban 'to do because of obligation'. Based on the lexical meaning, the word anetepi is categorized as a verb that functions as a predicate. This is evidenced by the relationship between the meaning of the word anetepi with other constituents that accompany it. Thus, the referential meaning of the word anetepi based on the relationship of meaning in the context of the cultural activities of the Metri Wayang Gandrung oral tradition refers to a condition in the form of a willingness to fulfil obligations that must be carried out by speakers. As for the contextual meaning: First, an appeal so that people do not forget the promises that have been made. Second, regardless of the circumstances and however far the distance, a promise that has been made must still be carried out.

3.10 Nyuwun ngapunten. The word nyuwun ngapunten is a compound word. In the Javanese Baoesastra [4]), the word nyuwun ngapunten means njaluk pangapura 'to apologize'. Based on the lexical meaning, the word nyuwun ngapunten is categorized as a verb that functions as a predicate. This is evidenced by the relationship of the meaning of the word nyuwun ngapunten with other constituents that accompany it. Thus, the referential meaning of the word nyuwun ngapunten based on the relationship of meaning in the context of the cultural activities of the Metri Wayang Gandrung oral tradition refers to an act of apologizing by the speaker to the ancestors. As for the cohesion analysis above, the speaker refers to Pak Akad (ritual leader) and Pak Ngadiyanto and his family. As for the contextual meaning: if someone makes a mistake, they should be brave enough to apologize. In addition, in the Metri Wayang Gandrung text, the word nyuwun ngapunten is repeated the most. This shows that Javanese people have high-minded to apologize even though they do not necessarily make mistakes.

\section{CONCLUSION}

Based on the results of the analysis and discussion above, the researcher concludes that the meaning of the discourse behind the Metri Wayang Gandrung contains messages that can be seen from 3 aspects, namely functional aspects, social aspects, and aspects of community life. First, when viewed from the functional aspect, the Metri Wayang Gandrung oral tradition is a medium for the community to express their desires in the process of living life. The wish was conveyed to their ancestors, namely Mbah Gandrung. The term Mbah in Javanese culture is closely related to ancestors. The meaning of the term Mbah Gandrung itself contextually gives a message about the value of respect for ancestors and a deep desire for welfare and life sustainability. The word Mbah in everyday context means parents of Father and Mother, the implied meaning of this term is an understanding of people who are respected as ancestors who started a generation, descendant or a family.

Second, when viewed from the social aspect, the Metri Wayang Gandrung oral tradition contains a message about human hope for a stable life and outer and inner perfection. In this case, humans must try and work hard. As for the process sometimes, humans cannot do it alone. This means that humans as social beings need the help of others, both moral and material support. Thus, social life in society will be created through the factor of meeting each other's needs.

Third, when viewed from the aspect of life, the Metri Wayang Gandrung oral tradition contains messages or teachings about the value of honesty through the understanding of becik ketitik ala ketara (if true, say true, if false, then say false). The honesty is manifested in the form of fulfilling promises. Usually in wanting something, someone says a nadzar (vow) which means saying a promise to do something if that desire can be achieved. In this case, a person who has a nadzar then he must carry out the nadzar after his desire is fulfilled. However, as God's creatures, humans cannot be separated from mistakes and forgetfulness. Every action that is being will be, or has been done is not perfect. Therefore, humans must have the courage to apologize if they forget their promises or when they make mistakes to others. Thus, humans will always be introspective and aware of what they are doing, so that they are more careful in living this life.

\section{REFERENCES}

[1] Halliday, M.A.K. dan Ruqaiya Hasan. (1976). Cohesion in English. London : Longman.

[2] Renkema, Jan. (2004). Introduction to Discourse Studies. Philadelphia: John Benjamins Publishing Company.

[3] Amri, M. Misbahul. (2016). Gelaran Ning Senés Tontonan: Drama Sosial Ritual Mungel dari Desa Pagung Kabupaten Kediri Jawa Timur. Disertasi. Depok: Universitas Indonesia 
[4] Poerwadarminta, W. J. S. (1939). Baoesastra Djawa. Batavia: Groningen J. B. Wolters Uitgevers-Maatschappij N. V.

[5] Heigham, Juanita \& Croker, Robert A. (2009). Qualitative Research in Applied Linguistics A Practical Intoduction. Fourth Edition. Britain: Palgrave Macmillan.

[6] Litosseliti, Lia. (2010). Research Methods in Linguistics. London: Continuum Intentional Publishing Group.

[7] Sibarani, Robert. (2004). Antropolinguistik: Antropologi Linguistik dan Linguistik Antropologi. Medan: Penerbit Poda.

[8] Sudaryanto. (2001). Tata Bahasa Baku Bahasa Jawa. Yogyakarta: Duta Wacana University Press.

[9] Kridalaksana, Harimurti. (2002). Struktur, Kategori, dan Fungsi dalam Sintaksis. Jakarta: Universitas Katolik Indonesia Atma Jaya.

[10] Wedhawati, dkk. (2001). Tata Bahasa Jawa Mutakhir. Jakarta: Pusat Bahasa. 